\title{
Contribution of reading comprehension ability and learning motivation to writing
}

\author{
Ria Wati ${ }^{1}$, Atmazaki ${ }^{2}$, Tressyalina ${ }^{3}$ \\ ${ }^{123}$ Universitas Negeri Padang, Padang - Indonesia, (watiria628@gmail.com)
}

\begin{abstract}
The purpose of this description. First, the contribution of reading comprehension of writing exposition texs ability. Second, the contribution learning motivation to writing exposition texs ability. Thirth, the contribution of reading comprehension ability and learning motivation to writing exposition texs ability students of class X SMA Negeri 2 Pariaman. This research was a quantitative research using correlational method. The results of the research are. The reading comprehension ability contribute significant by $87 \%$ to writing exposition texs ability. The learnig motivation contribute significant by $25,9 \%$ to writing exposition texs ability. The reading comprehension ability and learnig motivation together contribute by $87,1 \%$ to the writing exposition texs ability. Can conclusion is reading comprehension ability and learnig motivation together contribute and significant relationship to writing exposition ability.
\end{abstract}

Keywords: reading, comprehension, motivation, ability, exposition

\section{Introduction}

Writing is a creative process. As a creative process, writing must undergo a process that is consciously traversed and consciously also seen in relation to others, thus ending with a clear purpose (Semi, 2009: 6). Writing activities can't be separated from the literacy culture (Barton, Hamilton, \& Ivanic, 2000). People who are ordinary educated are called literat because they are able to do both. The reading and writing ability of Indonesian students is at the bottom of the list when compared to Asian children (Supriyoko, 2004). Research conducted by the IEA Study of Reading Literacy (Elly, 1992) and the Progress in International Reading Literacy Study (PIRLS) study (Baer, Baldi, Ayotte, \& Green, 2007) concluded that students' reading ability in Indonesia is still very low. The results of the United Nations Educational, Scientific and Cultural Organization (UNESCO) survey in 2011 show that Indonesia's reading level index is the lowest in ASEAN. The ratio of reading fondness in Indonesia is only about $0.001 \%$, meaning that from 1000 people of Indonesia, there is only one person who likes to read. This puts Indonesia at the position of 124 out of 187 countries in the assessment of the Human Development Index (HDI) (Shihab, 2016).

Referring to the research results of the Program for International Student Assessment (PISA), data obtained that the reading and writing culture of Indonesia in 2012 the second worst of 65 countries in the world. In the same position PISA also placed the reading position of Indonesian students in the 57th of 65 countries studied. Furthermore, in 2015 PISA also stated that students' reading ability in 
Indonesia ranks 69 th out of the 76 countries surveyed. The result was lower than Vietnam which ranks 12th out of the total countries surveyed. Central Bureau of Statistics (BPS) in 2013 shows that Indonesian people who choose to read newspapers, books or magazines are $17.66 \%$, people who prefer to watch television and listen to the radio almost $91.68 \%$.

Writing skills is a very important language skill for students. Graham, Bollinger, Olson, D'Aoust, McCutchen, \& Olinghouse (2012: 6), stated that students who develop strong writing skills at an early age obtain valuable tools for learning, communicating, expressing themselves, helping them succeed in school and community. According to the views of Bunga and Hayes, writing is a complex process involving a number of cognitive and metacognitive activities. In addition, according to Hadley, writing requires composing, meaning the ability to tell or retell pieces of information in the form of narration or description, or to transform information into new texts, such as in expository or argumentative writings (Negari, 2011).

Writing has been studied since elementary school students. However, writing learning is still regarded as one of the difficult learning for students. This is in accordance with the results of interviews with two students of class X SMA Negeri 2 Pariaman, namely Novira Rosya and Princess Mardiah. Obtained information as follows. First, the student thinks that writing is a difficult activity because in writing is required to put ideas into written form with a regular order of sentences, meaning that one sentence with each other must be related. Second, students assume that writing a boring activity. Third, students consider writing activities less useful. Fourth, lack of reference. Fifth, teachers use less varied learning methods, especially in writing.

Research conducted by Aji (2015) that there are some problems found in exposition writing lessons. (1) The writing activities in the school have not enough attention from the students. (2) Students' motivation toward writing is still low because students assume that writing is a difficult activity compared to four other language skills. (3) Students have difficulties in finding and pouring ideas in writing lessons. (4) The learning model used is less interesting so that it needs a more elevated learning model to improve the students' motivation in writing exposition. (5) The media used does not attract students' attention.

Reading is a reference for writing. So, how can someone write if you do not like reading (Head of Bandung Language Center Abdul Khak in Kompas Daily, November 23, 2011). Reading comprehension is the reader's ability to recite the content of reading, whether it be reading arguments, expositions, or reading descriptions on a particular topic (Razak, 2005: 11). Reading comprehension can also be said to read in the heart. That is, reading is done without sound or sound (Agustina, 2008: 15). Reading comprehension is a kind of reading activity that seeks to interpret experiences, connect new information with known ones, and find answers to cognitive questions from written material (Tarigan, 2008: 43).

Based on the above explanation, the purpose of this research are: (1) to explain the contribution of reading comprehension ability with the ability to write expository text of class $\mathrm{X}$ students of State Senior High School of Pariaman City; (2) to explain the contribution of learning motivation with the ability to write exposition of class X students of State Senior High School of Pariaman; (3) explain the contribution of reading comprehension ability and learning motivation with the ability to write expositions of students of class X State Senior High School of Pariaman.

\section{Method}

The type of research is quantitative with correlational descriptive method. The population of this study is all students of class X SMA Negeri 1 and 2 Pariaman city registered academic year 2016/2017 with the number of 614 students spread in twenty classes. In this study the amount of samples taken as much as $20 \%$ of the population with random sampling technique. Thus, the number of samples of 
this study were 118 students. This study consists of three variables, namely: (1) the ability to write exposition text of class $\mathrm{X}$ students of SMA Negeri Pariaman as bound veriabel $(\mathrm{Y})$, (2) reading comprehension ability of grade X SMA Negeri Pariaman as independent variable variable (X1), and (3) the motivation of students of class X SMA Negeri Pariaman as free veriabel (X2).

\section{Result}

1. Ability of Writing Text Exposition (Y) Student Class X State Senior High School of Pariaman.

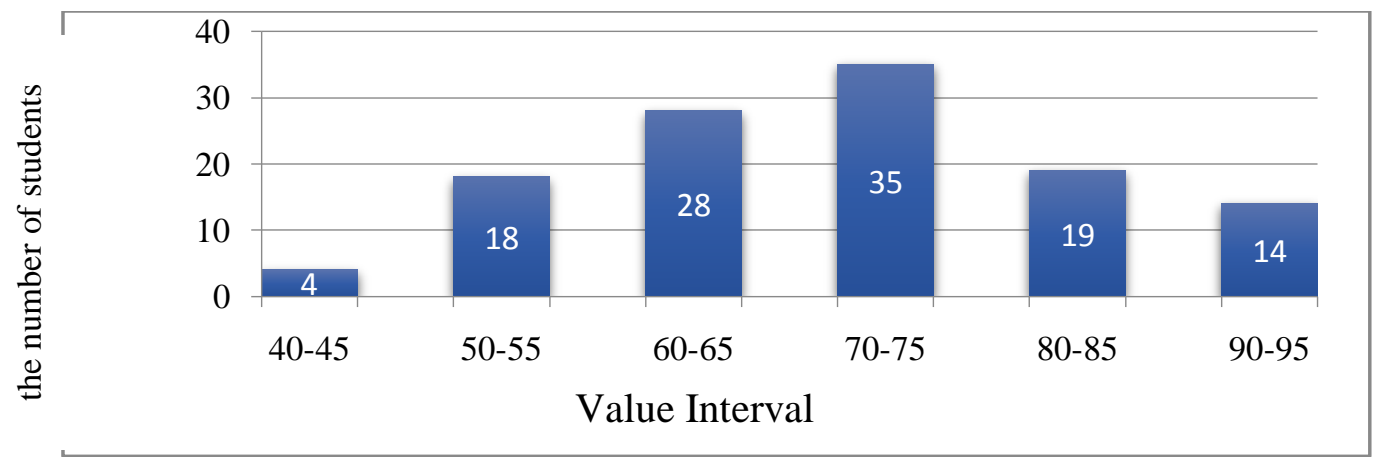

Picture 1. Histogram Distribution Value Ability Writing Text Exposition

Student Class X State Senior High School Pariaman

Based on Figure 1, the lowest interval score achieved by students is $40-45$ as many as 4 students, while the highest interval value is $90-95$ as many as 14 students. Obtained average ability to write exposition text students of class X State Senior High School Pariaman is 70 is in the qualification is more than enough.

2. Reading Ability Understanding (X1) Student Class X State Senior High School Pariaman

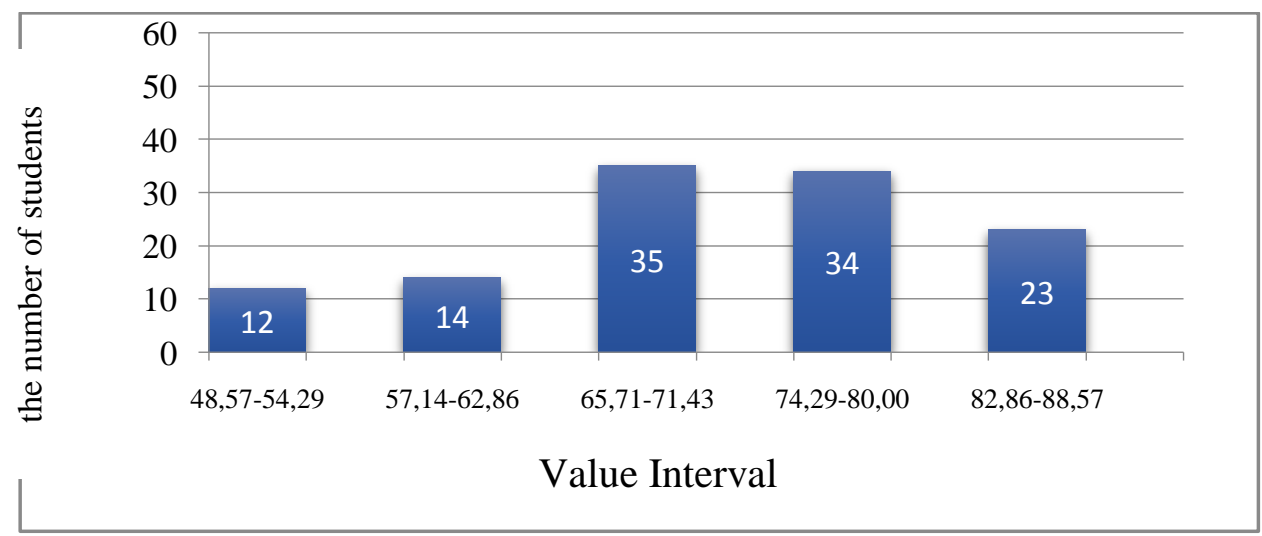

Picture 2. Histogram Distribution Value Reading Ability Understanding Student Class X State Senior High School Pariaman

Based on Figure 2, the lowest interval score of students' reading comprehension is $48,57-57,29$ as many as 12 students, while the highest interval value is $82,86-88,57$ as many as 23 students. Obtained average ability to read the understanding of students class X State Senior High School Pariaman that is 71.77 is in the qualification is more than enough.

3. Student Learning Motivation Class X State Senior High School Pariaman 


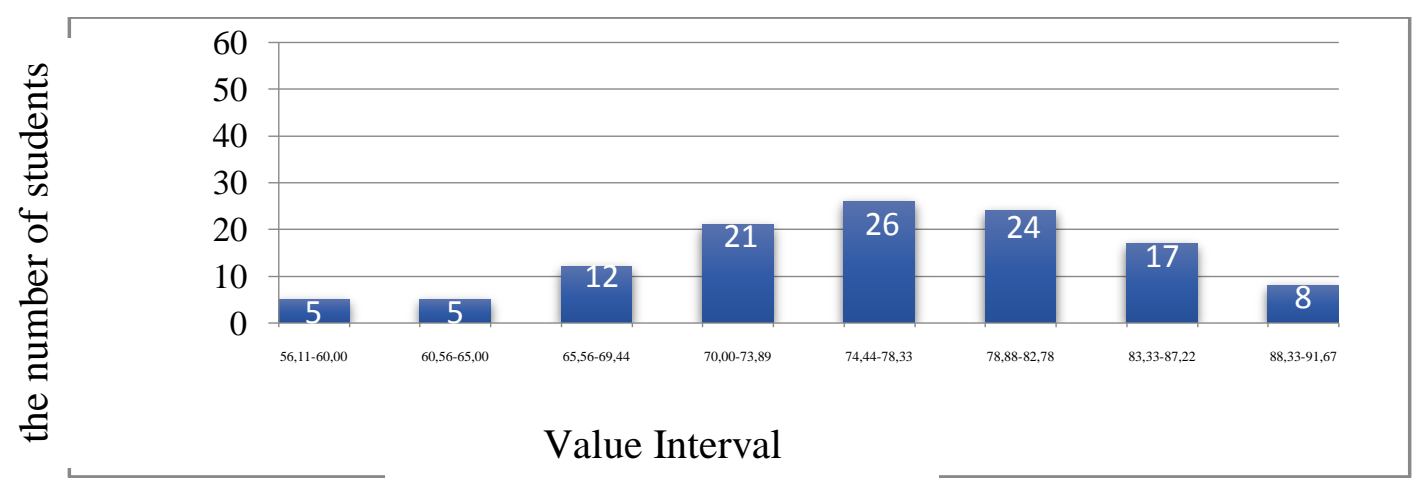

Picture 3. Histogram Distribution of Learning Motivation Values Student Class X State Senior High School Pariaman.

Based on figure 3 above, the lowest interval of learning motivation achieved by students is 56,11-60 counted 5 students, while highest interval value is 88,33-91,67 counted 8 student. Obtained average ability to read the understanding of students class X State Senior High School Pariaman is 76.14 is in the qualification is more than enough.

\section{Discussion}

1. Contribution of Reading Ability Understanding of Writing Capability Text Exposition (Y) Student Class X State Senior High School Pariaman.

The ability to read comprehension is needed by students in the learning process so that every reading can increase insight. As per Razak's opinion (2002: 1) that reading is an important activity. Through reading one can get ideas. The idea can be developed so that from reading the understanding that it can produce a writing. It can be concluded that there is a link between the ability to read comprehension and the ability to write an exposition. This is reinforced with research data about the ability to read comprehension contributed $87.1 \%$ to the ability of writing exposition texts.

Referring to a study conducted by Delfianto (2016), the results showed that comprehension reading contributed significantly by $23.2 \%$ of the ability to write descriptive responsive text. The better the students' reading comprehension the better the writing ability of the students. The Meniado study (2016) also supports this research. The results show that reading strategy and motivation for reading is an important factor in achieving reading level. There is a positive correlation between reading and motivation to read to read on learning outcomes.

2. Student Motivation Contribution Contribution to Ability of Writing Text Exposition

Ability to write expositional text of students is influenced by student learning motivation. The higher the students' learning motivation, the higher their writing skills. The findings of this study are in line with Sardiman's opinion (2012: 73) that "motivation" comes from the word "motive", which means as the power of effort that drives someone to do something. Motives can be said as the driving force of the subject to perform certain activities in order to achieve a goal. Furthermore, Prawira (2014: 350) states that learning motivation can be interpreted as an overall driving force within the students that leads to learning activities that ensure continuity of learning activities and provide direction on learning activities, so that the goals desired by the subject of learning can be achieved.

Based on the above statement, learning motivation greatly contributes to the ability of writing expositions. Motivation to learn is one factor that contributes to the ability to write. The higher the students' learning motivation, the higher the writing ability. Thus, the low ability to write students can be pursued by improving students' learning motivation. Teachers and parents need to work to 
improve students' learning motivation to optimize student learning outcomes. Learning motivation becomes an important factor in the learning process.

3. Contribution of Reading Ability Understanding and Motivation of Student Learning on Ability to Write Exposition Text

The coefficient of reading comprehension and student's learning motivation together with the ability to write exposition text are quite strong. Furthermore, students' reading comprehension and motivation skills together contribute significantly to the ability to write expository texts. This suggests that the ability to write student expositions is influenced by their students' reading comprehension and learning motivation. Therefore, the ability to read understanding and motivation to learn students should get more attention from students and teachers in the State Senior High School Pariaman especially in class X.

The ability to read comprehension must be mastered by every student because reading ability is important. A person who has the ability to read a good understanding will easily get information from reading readings. The better the understanding of the readings the easier it is for a person to receive and impart information. Motivation to learn is an encouragement that arises in students to learn or gain knowledge so that there is a change in students to a better direction. Each student must have a motivation in learning, so that the learning objectives that have been planned by the teacher can be achieved. Therefore, teachers should be able to generate student motivation in learning. Many ways can be done by teachers to motivate students in learning, one of which is to design a way of learning to appeal to students. Most of which make students less motivated in learning, that less interesting lesson. Therefore, it is impossible for a person to put his ideas into writing without being motivated to learn. The higher the students' learning motivation, the higher the writing ability. Thus, the low ability to write students can be pursued by improving students' learning motivation. Teachers and parents need to work to improve students' learning motivation to optimize student learning outcomes. Learning motivation becomes an important factor in the learning process.

\section{Conclusions}

There is a positive and significant contribution between the ability to read the understanding of the ability to write exposition of the text of students of class X State Senior High School Pariaman. The contribution of reading comprehension to writing exposition is $87 \%$. Positive and significant contributions also exist between the ability to read comprehension and motivation to learn the ability to write exposition text students of class X State Senior High School Pariaman. The contribution of learning motivation to writing exposition is $25.9 \%$. Furthermore, there is a contribution to the ability to read comprehension and motivation to learn together to the ability to write exposition of the text of students of class X State Senior High School Pariaman Donations ability to read comprehension and learning motivation to the ability to write exposition jointly is equal to $87.1 \%$. That is, $87.1 \%$ of exposition writing ability is influenced by reading comprehension ability and learning motivation, while the remaining $12,9 \%$ is determined by other factors not examined in this research.

\section{Acknowledments}

The process of writing this article can be completed on the guidance of various parties. Therefore, on this occasion the author would like to thank (1) Prof. Dr. Atmazaki, M.Pd., as advisor 1 and Dr. Tressyalina, M.Pd., as advisor 2, Examiners; Prof. Dr. Harris Effendi Thahar, M.Pd., Dr. Afnita, M.Pd., and Prof. Dr. Ahmad Fauzan, M.Sc. Furthermore, I would like to thank the lecturer of Indonesian Language Education who has contributed the science to this research. Do not forget to also thank the parents who have provided meteri and spirit support in completing this research. 


\section{References}

Aji, A.R.B. (2015). Peningkatan keterampilan menulis eksposisi melalui model pembelajaran member dan menerima pada siswa kelas VII E SMP Wates Kebupaten Kulon Progo DIY: Yogyakarta. Universitas Negeri Yogyakarta.

Atmazaki. (2006). Kiat-kiat mengarang dan menyunting. Padang: UNP Press.

Baer, J., Baldi, S., Ayotte, K., \& Green, P. J. (2007). “The reading literacy of US fourth-grade students in an international context: results from the 2001 and 2006 progress in international reading literacy study (PIRLS)."

Barton, D., Hamilton, M., \& Ivanic, R. (2000). Situated Literacy, Reading and Writing in Context. London: Rotlegde.

Haliza, E. (2016). The releationship between vocabulary size and reading comprehension of ESL learners English language teaching, Volume 9, No. 2, Tahun 2016, ISSN 1916-4742, E-ISSN 1916-4750.

Junaedi, A.N.(2016). "Keefektifan pendekatan pada proses pembelajaran menulis teks eksposisi siswa kelas X SMA Negeri 1 Cisaat Kabupaten Sukabumi Jawa Barat" Skripsi. Yogyakarta. Universitas Negeri Yogyakarta.

Kemendikbud. (2013). (Buku siswa) bahasa Indonesia ekspresi diri dan akademik untuk SMA/MA kelas X. Jakarta: Kementrian pendidikan dan kebudayaan.

Mediado, Joel C. (2016). Motecognitive reading strategies, motivation, and reading comprehension performance of saudi efl student" English Language teaching, Volume 9, No 3, Tahun 2006, ISSN 1916-4742, E-ISSN 1916-4750.

Nadjwa, A. (2011). "Analisis koherensi". (Online). (file://User/Acer/Downloads/wacana/pengertiankoherensi.html, diunduh 10 November 2016.

Razak, A. (2007). Membaca pemahaman. teori dan aplikasi pengajaran. Pekanbaru: Autografika.

Republika"Literasi indonesia sangat rendah". (Online),

(http://www.republika.co.id/berita/koran/didaktika/14/12/15/ngm3g840literasi-indonesia-sangatrendah, diakses 6 Oktober 2016).

Sardiman. (2011). Interaksi dan motivasi belajar mengajar. Jakarta: Raja Grafindo Persada.

Semi, M. A. (2009). Menulis efektif. Padang: Angkasa Raya.

Shihab, N. (2016). "Menikam kolonialisme dan merdeka dengan buku”. (Online), (http://edukasi.kompas.com/read/2016/08/18/11140791/menikam.kolonialisme.dan.merdeka.den gan.buku, diakses 5 Oktober 2016).

Sugiyono. (2012). Statistika untuk pengajaran. Bandung: Alfabeta.

Tarigan, H.G. (2008). Menulis sebagai suatu keterampilan berbahasa. Bandung: Angkasa.

Uno, H.B. (2011). Teori motivasi dan pengukurannya. Jakarta: Bumi Aksara. 